\title{
AGE, GROWTH AND CHANGES OF WEIGHT PROPORTIONS AND OF CHEMICAL COMPOSITION OF EEL DURING ITS LIFE IN POLISH WATERS
}

\section{WIEK, WZROST I ZMIANY STOSUNKÓW WAGOWYCH ORAZ SKEADU CHEMICZNEGO WEGORZA W CZASIE JEGO ŻYCIA W WODACH POLSKI}

From Department of Ichthyology

Head: Prof. Dr. Walerian Cięglewicz

The author had studied the age and rate of growth, the weight increase and the chemical compositions of eels living under the most typical conditions, such as : sea, littoral waters and inland lakes. The investigated material comprised 646 specimen of fish; out of this 499 represented the yellow eel (282 migrating from sea and river estuaries, 151 from Firth of Vistula River and 66 from inland lakes ) and 96 represented the silver eels migrating to sea for spawning.

258 pieces were examined technologically and 158 were subjected to chemical analysis for content of proteins, fats, water and mineral compounds.

The highest content of fat was found at the silver eels; lower content was noted at eels living in bays and still lower content, at eels living in lakes. The lowest rate of fat increase was observed at eels from inland lakes.

Author concludes, that the content of fat in meat tissue is one of the characteristic conditions for silver eel, which stimulates it for spawning migrations.

The existing literature in eel comprises strictly limited part of the problems such as, biological or technochemical, but does not com- 
prise the problems in any complex form. Upto now, in Poland no detailed investigations have been carried out on the subject of eel.

Aim of the present work was to determine the growth, changes in weight proportions and in chemical compositions of the eels living in Polish waters, with due consideration to the most typical conditions in economical aspect, such as:
Baltic Sea - migrating and feeding (yellow eel) and silver eel
Mazurian Lakes - feeding, eel (yellow)
Firth of Vistula River - feeding eel (yel- low).

The results of technochemical analysis permitted to define the usable and consumptive values of the fish.

\section{MATERIAL AND METHODS}

The material for investigations was collected during 1961 and comprised: montée - French Atlantic Coast (10.4.61) - 51 pieces

bay eel - Firth of Vistula River (15.4. to 10.7.61) - 151 pcs.

moving inshore eel - Swibno, Eeba and Gdańsk Bay (10.4. to 10.11.61)

- 282 pcs.

lake eel - Fish Industries Ruciane (Mazurian) (15.4. to 12.9.61) - 66 pcs. silver eel - Sea, in vicinity of Jastarnia (15.10. to 10.11.61) - 96 pcs.

For age, 595 eels of Polish waters had been examined with comparison of 51 pcs of montée, supplied from France.

For determination of sex, accepted the principle,that the mesenteric organ represents the female's, while the ribbonform - the male's organ. Such principles of sex determination by macroscopic differences, in spite of their wide application, are questioned by some investigators. E.G. T e s c h (1928) ascertained, that Syrski's organ is an undeveloped form of gonads and therefore is baseless in determination of sex.

The eel ovaries, also called Krause's organs, resemble the creased frill fastened dorsally to middle dorsal part of abdominal cavity ( $G$ i r s z t o w t t, 1961). The non-fastened end of ovaries is longer than the suspended one and this forms a mesentery, or so called mesenteric orgar. According to the same authoress, the width of ovaries depends on the length of fish and it amounts from 3,4 $\mathrm{mm}$ for $33,0 \mathrm{~cm}$ of length to $8,0 \mathrm{~mm}$ at $49,2 \mathrm{~cm}$ of length. Extending 
on the both sides of kedney, the ovaries protrude beyond the rectum with slight narroving towards the backend. The surface of ovaries is not even on the both sides; it is directed towards the abdominal lobes which comprise reproductive cells, while the inner side is smooth. At young eels, the ovaries are translucent and are becoming white to yellowish during their growth.

At length of ab. $30 \mathrm{~cm}$ (Suvor o v, 1954), the nucleus called Syrski's organs can be distinguished; they may be of racemoseform, or lobal comprising upto 50 of lobs, and are situated similarly to ovaries. At fish of 27 to $37 \mathrm{~cm}$ in length, they appear like a string of pearls of the thickness width from 0.1 to $0.2 \mathrm{~cm}$. In the posterior narrowed part, the thicknesses are visible under 5-times magnifying. The nucleus, which generally are translucent or semitranslucent, may became milky-white, as noted at some specimen caught in sea during the Autumn.

Sex of the examined eels was defined according to the above-given description; all fishes with fully developed mesenteric organ were considered to be female and with organs of ribbonformas males. The specimen with sex organs not clearly developed were considered in the third group as non-identified sex.

The yellow eel was fished with basket-nets and setting-nets of a fine mesh, the bay-eel with basket-nets and strings, while the silver eel - with set-nets.

To the group of silver eel, were accounted entirely the fishes possessing

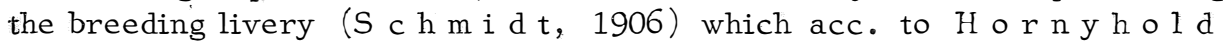
(1922), are acquiring the males of 24 to $51 \mathrm{~cm}$ in length and the females of 37 to $100 \mathrm{~cm}$ in length. Fishes of this group are characteristic for well grown-in scale, richly appearing mucus, dark colour of dorsal part and of glasy-white abdominal part. Comparing toyellow eels, the eyes of these eels are distinctly larger. Degeneration of alimentary canal, its decreased passage and appearance pseudo-mucus substance, was noted at sections, what complies with investigation results of $\mathrm{S} c \mathrm{~h} \mathrm{n}$ a c k e n b e c k (1953).

The eels caught in the sea, but not showing the above-given characteristics, and the feeding fish from remaining environments, were accounted to the yellow-eel group.

The age was estimated by otoliths method, which ensures the most definite results ( $\mathrm{E} \mathrm{hre} \mathrm{n} \mathrm{b} \mathrm{a} \mathrm{m} \mathrm{and} M$ a rukova, 1913). According to investigations of other authors, suchas: Gonzoe (1908), E h r e n b a u m and Marukova (1913) and T e s c h (1928), the scale method does not ensure such guarantee. The moment of scaling, according to the above mentioned authors, is dependen on the length of fish and not its age. Usually, the scales start growing after the fish spent minimum 2-5 years in fresh or freshened waters and at its scaling length $(16$ to $20 \mathrm{~cm})$, irrespectably of age.

The otoliths come into existance and grow in relation to fish age. The age calculated by otoliths and by scale method gives differences of 1 to 5 years only due to delayed and variously starting period of scaling ( $F \mathrm{r} \circ \mathrm{s} \mathrm{t}, 1945$; T hu r o w, 1930). Additional difficulty in estimating the age by scaling method is due to fact, that the quantity of annual rings varies at the same specimen. According to Frost, the difference may amount from 5 to 13 at fish 
length of $69 \mathrm{~cm}$. Some part of rings is not complete and their appearance is not subsequent. (Hornyhold ascertained only 0.07 per cent of scales with maximum quantity of zones). Finally, according to the above-mentioned authors the scales cease growing from certain, clearly not defined, age.

The otoliths were accessible after flat cutting towards the snout of skull upper part, uncovering and removing of brain. Thus, the otoliths were vi. sible and easely removable. Directly after removing, the otoliths were delicately cleaned with cloth and thenafter flushed in alcohol for 24 hours.

After grinding of the convex side, the otoliths were placed on a plate and floaded with Canadian balm.

No distinct differences were noted in counting the number of rings by other methods; however, the method of keeping them dry and then for 24 hours in alcohol, proved the best results. In the course of further experiments ascertained, that the otoliths should not be dry-stored for longer than 2 weeks; after such time they become dull and their rings obliterate, what causes the age reading very difficult. One the most important moments for exact reading of otoliths age is their proper grinding. For this purpose was used a fine-grade stone and the convex side of otolith was ground to obtain good visibility of nuclei; frequent check of result was made under magnifying glass.

The following interpretation of results was applied for determination of age: usually, but not in every case, three very narrow rings of white colour appeared around the nuclei; this was taken as corresponding to 3 Summer seasons of living in sea. Thenafter, divided by dark narrow ring, appeared white and wide zone of the first Summer season in fresh or freshened water; next narrow for Winter season, and soon. The fully developed Winter rings were considered only.

The reading difficulty of otoliths was due to the very narrow rings, frequently of compound type in preparation it is very difficult to grind thoroughly the edges. Summer and Winter zones can hardly be distinguished at the elder eels at which in progression to age, the rings are getting more close and more difficult for reading. Condisering such difficulties, the biologists agree, that the age determination at eels of above 7 years life in fresh water is problematic and frequently within the error of 1 to 2 years.

According to $\mathrm{N}$ ordquist and Vallin (1923), the otoliths grow during the whole period of eel's life including the period of reduction in length. With the years, the beginning of otoliths growth is retarded and starts appearing in July; therefore, in determination of age, considered the completed Winter ring. The age proper was expressed in age-groups denoting the quantity of years lived in fresh or freshened waters, but excluding the larval stadium, montée, and young-fish time, and was marked by Roman digits. Thus, for determination of fish age, three years spent previously in sea, must be added to age-group.

The data relating to eels investigated was collected according to defined scheme; length of particular parts was measured and thenafter, the whole body, head, intestinals, liver, bones, skin, fillets and gonads were weighed in gramms. Calculated was: the content of protein in meat tissue according to Kieldahl's method, of water (by desiccation method - $105^{\circ} \mathrm{C}$ ), of fat according to Scxhlet, of ash (by burning), and the other. 
This material was collected regardless to sex, as this was impossible for determination by exterior characteristics. As certain guidance in sex determination may be taken the size of fish, as it is known, that the length of male is limited to about $45 \mathrm{~cm}$.

The obtained data relating to age, length and weight was presented on the tables and it expresses the proportions of length and weight to age-groups. Such form of representation allows for comparison of own results with the results of other authors, who investigated the growth of eel under specified or diametrally different conditions and environments.

The rate of eel growth was calculated by the author on the basis of average length and weight in particular age-groups without the back calculations; owing to hardly ligible and small otoliths, the measurement of annual rings was not tenable.

\section{RESULTS}

\section{A. Biologic characteristics - age and growth of eels investigated}

The examined 51 pcs of montée supplied from France, represented entirely the group 0. The length of fish was 7 to $9 \mathrm{~cm}$ and weight 0.25-0.35 g. This was not already glassy eel, but the young fish in various studies of pigmentation, which was appearing particularly intensively along the sidelines. The skin of dorsal part of body and of head did not contain pigment yet.

Y e $110 \mathrm{w}$ e e 1 - is represented in three groups depending on environments of catching.

Ascending moving inshore eel - caught in the vicinity of sea coast at Sopot and at estuaries of Vistula and $E$ eba, represented nine groups of age from I to IX in quantity from 1 to 85 pcs. Of the total quantity 282 pcs, sex was identified at 241 and this represented 34 males and 207 females. At the remaining 41 pcs, no sex could be identified owing to small size of fish and not sufficiently developed gonads.

Wide range in sizes and age of eels accounted to that group, may be explained by the facts, that besides the fish migrating to fresh waters, were also caught some fishes remaining there temporarily and those, which could remain in these waters until the breeding migration. There was no possibility to divide these fishes according to above mentioned scheme, as non possessed the breading livery and thus, all of them were accepted under the common definition as ascending.

The total age of ascending eel oscillates, according to obtained data, between 3 and 12 years (group I to IX), with average of 8 years (group V), corresponding to body weight $64.8 \mathrm{~g}$ and to length of $33.6 \mathrm{~cm}$. In material investigated, the most numberous were eels of age-group IV to VI amounting to 76.2 per cent. The same data in relation to sex proved the increasing 
weight of females in relation to males with growth of age from 0 per cent in group III to 19 per cent in group VII.

B a y e e 1 - was represented by 151 pcs, entirely females; no males were identified. The average age of fish belonging to twelve age-groups (III to XIV) was 10.0 years at weight of $163.0 \mathrm{~g}$ and at length of $42.3 \mathrm{~cm}$. Most numberous was the age-group VI amounting to 27.8 per cent and the fish of length 36 to $40 \mathrm{~cm}$, amounting to 30 per cent. The widest range in length of $31 \mathrm{~cm}$ was noted in group XIII (from 57 to $88 \mathrm{~cm}$ ).

L a k e e e 1 - the 66 pcs, which represent this environment, belonged to eleven age-groups from IX to XX. The average age was 15.7 year, at weight of $698 \mathrm{~g}$ and at length of $65.9 \mathrm{~cm}$. Most numberous was the age-group XII amounting to 26.8 per cent.

General remarks relating to age and growth of yellow eel

Eel originating from the three above-mentioned waters (sea, bay and lakes) was represented in nineteen age-groups in quantity of 1 to 131 pcs; most numberous was the group VI, amounting to 26 per cent. Average age was 9.7 year at weight of $136.5 \mathrm{~g}$ and at length of $36.2 \mathrm{~cm}$. The widest range of fish length $(32 \mathrm{~cm})$ was noted in age-group XIII $(55$ to $87 \mathrm{~cm}$ ) and $860 \mathrm{~g}$ in weight at XIV (840 to $1700 \mathrm{~g})$. The collected data is represented in Table 1.

Length and weight of the yellow eel in the particular age-groups, as cair culated on the basis of all material collected from various regions, is presented on Fig. 1 and 2.

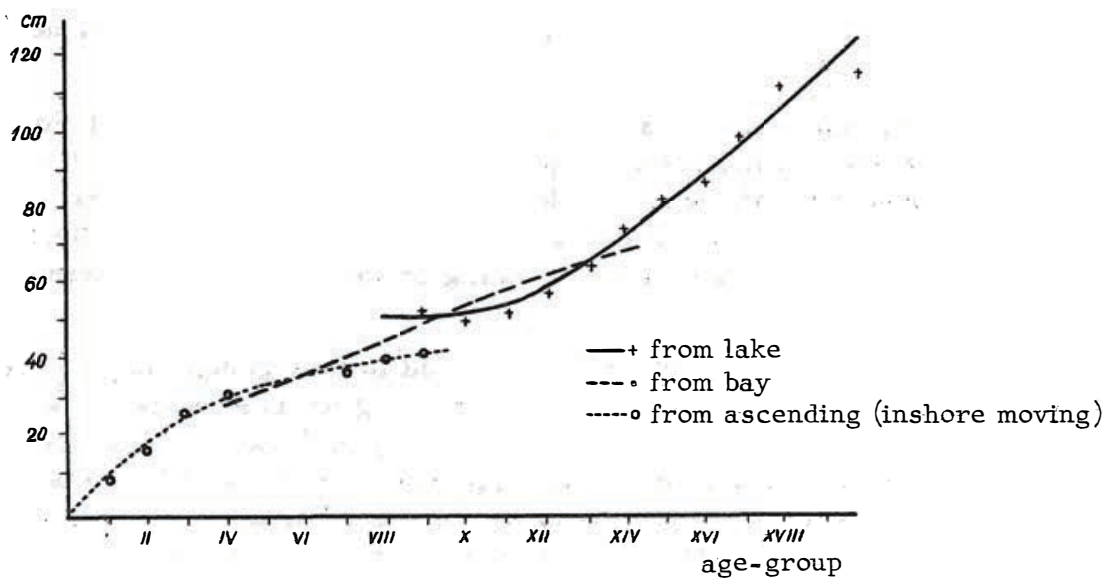

Fig.1. Length of yellow eel in age-groups

On average, ascending (movinginshore) eel shows by one year higher age than bay eel of the same length. This proves, that the bay eel has better rate of growth than the ascending eel. Annualincrease of bay fish is proportional to its growth and, contrary to ascending fish, tends to be increamental. This 
Table 1

Length, weight and age of yellow eel

\begin{tabular}{|l|c|c|c|c|c|c|c|c|c|c|}
\hline Age-group & I & II & III & IV & V & VI & VII & VIII & IX & X \\
\hline Length (cm) & 11.0 & 18.0 & 26.7 & 31.0 & 34.6 & 34.7 & 39.4 & 46.0 & 46.8 & 52.5 \\
Range of length & - & $11-25$ & $20-34$ & $21-39$ & $28-41$ & $31-51$ & $28-48$ & $38-58$ & $41-57$ & $48-58$ \\
Weight (g) & 1.5 & 11.0 & 28.4 & 51.3 & 62.8 & 75.8 & 98.1 & 180.4 & 241.3 & 257.9 \\
Range of weight & - & $2.5-45$ & $6-65$ & $25-90$ & $42-110$ & $45-220$ & $35-200$ & $75-440$ & $120-520$ & $200-300$ \\
Quantity of fish & 1 & 11 & 27 & 71 & 104 & 131 & 36 & 16 & 18 & 12 \\
Per cent & 0.2 & 2.2 & 5.4 & 14.2 & 20.8 & 26.2 & 7.2 & 3.2 & 3.6 & 2.4 \\
\hline Age-group & XI & XII & XIII & XIV & XV & XVI & XVII & XVIII & XX & Average \\
\hline Length (cm) & 55.2 & 59.8 & 66.8 & 72.2 & 82.2 & 87.3 & 98 & 112 & 125 & 36.2 \\
Range of length & $47-63$ & $51-67$ & $55-87$ & $59-81$ & $74-88$ & $78-96$ & - & - & - \\
Weight (g) & 341.3 & 485.0 & 627.4 & 768.8 & 1065.7 & 1280.0 & 1320.0 & 2700 & 2750 & 136.5 \\
Range of weight & $195-510$ & $380-590$ & $450-980$ & $490-1100$ & $630-1360$ & $840-1700$ & - & - & - & 1 \\
Quantity of fish & 11 & 28 & 18 & 9 & 7 & 3 & 1 & 1 & 1 \\
Per cent & 2.2 & 5.6 & 3.6 & 1.8 & 1.4 & 0.6 & 0.2 & 0.2 & 0.2 \\
\hline
\end{tabular}




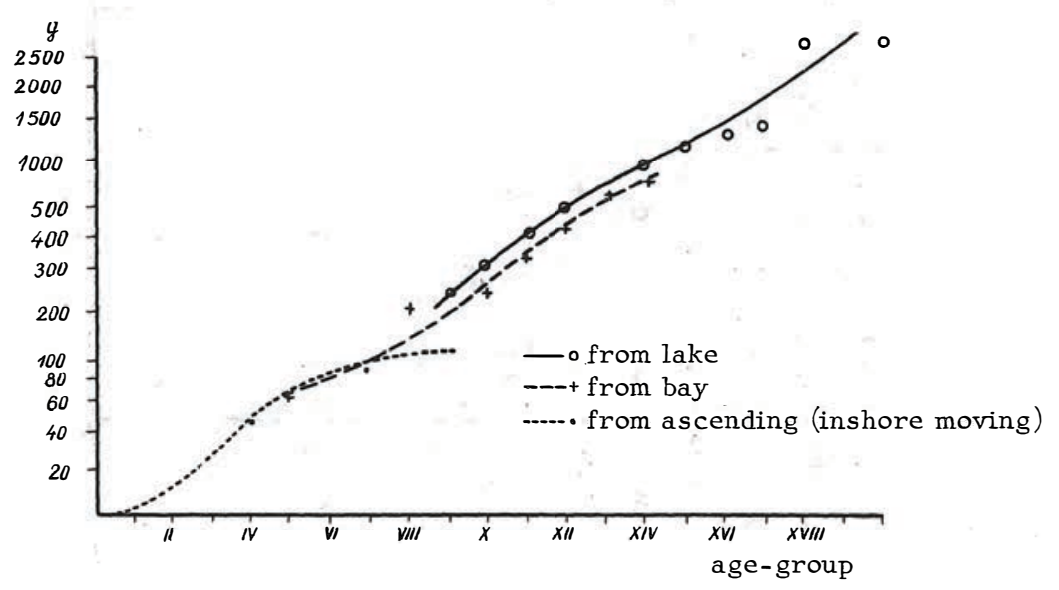

Fig.2. Weight of yellow eel in age-groups

same increasing phenomenom applied to lake eel, when comparing it to bay eel. While within the groups IX to XII, the lake eel proves lower increase than bay eel, it shows intensified increase in length between the XIII and XVIII groups.

It may generally be ascerted, that comparatively to other species, the increasing rate of yellow eel is slow; although, some of them show considerable deviations in both directions, i.e. in length and weight. During its life within the fresh and freshened waters, the yellow eel proves three indifferent growing periods, viz.: intensive growth from I to VI group, slower rate between VI and XII, and again intensified thenafter. These periods are related to subsequent living environments, i.e. sea, bay, lakes.

The characteristics given above, comply with the observation results of other authors, except $\mathrm{T} \mathrm{hu} \mathrm{row} \mathrm{(1959).} \mathrm{He} \mathrm{ascerts} \mathrm{that,} \mathrm{owing} \mathrm{to} \mathrm{com-}$ mulation of fat in tissues, the growth is falling-down to zero beginning from thirteenth group. The present investigations lead to conclusion, that the eel is growing throughoutits whole span of life but its rate of growth is changing only .

The differences in rate of fish growth amoung annual environments should be explained by different biochemical and physical conditions. Mainly, by abudance of nourishment, by density of fish, and by temperature which decides on intensivity and length of feeding period (B e $r$ t i n 1957).

Comparing to fish of Windermere ( $F r \circ s t, 1945)$, the eels of Polish waters are of higher weight, except for group XI and XIV; compared with eels from Elbe ( $G$ e $\mathrm{mz}$ o e, 1908), higher weight is noted until the group V. The eels from Alster (Gem zoe, 1908) and from Cemaccio (B e 11 i n i, 1910) were of larger sizes within the same age-groups than the eels from Polish waters. Such comparison is represented on Fig.3.

The wide-headed eels proved generally the weaker condition than the narrow-headed, what complies with observations of F r o s (1945). The collected material allows to conclude, that attainable sizes are close for both 
Length, weight and age of silver female eel

\begin{tabular}{|l|c|c|c|c|c|c|c|c|}
\hline \multicolumn{1}{|c|}{ Age-group } & VIII & X & XI & XII & XIII & XIV & XV & XVI \\
\hline Length (cm) & 49.0 & 53.0 & 59.8 & 64.8 & 70.6 & 74.7 & 74.7 & 64.0 \\
Range of length & $48-50$ & $48-58$ & $54-65$ & $56-76$ & $59-83$ & $62-90$ & 73.6 & - \\
Weight (g) & 172.5 & 190.0 & 349.5 & 506.0 & 678.3 & 802.1 & 776.6 & 450.0 \\
Range of weight & $170-175$ & $230-36.0$ & $290-465$ & $325-980$ & $320-1100$ & $330-1400$ & $710-820$ & - \\
Quantity of fish & 2 & 6 & 10 & 15 & 9 & 12 & 3 & 1 \\
Per cent & 3.4 & 10.8 & 16.9 & 25.4 & 15.2 & 20.3 & 5.1 & 1.7 \\
\hline
\end{tabular}

T a b l e 3

Length, weight and age of silver male eel

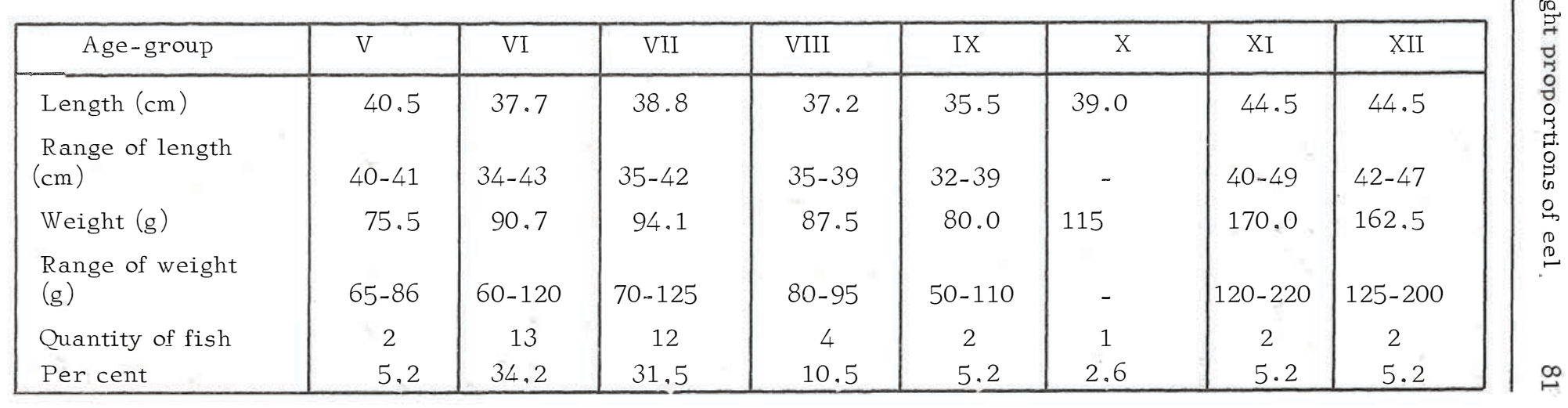


the narrow-headed and wide-headed eels. This is contrary to ascertion of E h r e n b a u m (1930), who considered, that the narrow-headed eels grow to weight of 1.5 pound only, and the wide-headed grow above that.

S i l ve $r$ e e l. This group of eels was represented by 38 males and 58 females. The females were accounted to age-groups from VIII to XVI with most numberous (upto 25.4 per cent) in group XII. Their average length was $64.5 \mathrm{~cm}$ and weight $524 \mathrm{~g}$. Particular data is presented in Table 2.

The males were considered in eight age-groups from V to XII with most numberous (upto 34.2 per cent) in group VI. Their average length was $37.7 \mathrm{~cm}$ and weight $90.7 \mathrm{~g}$. Particular data is presented in table 3 .

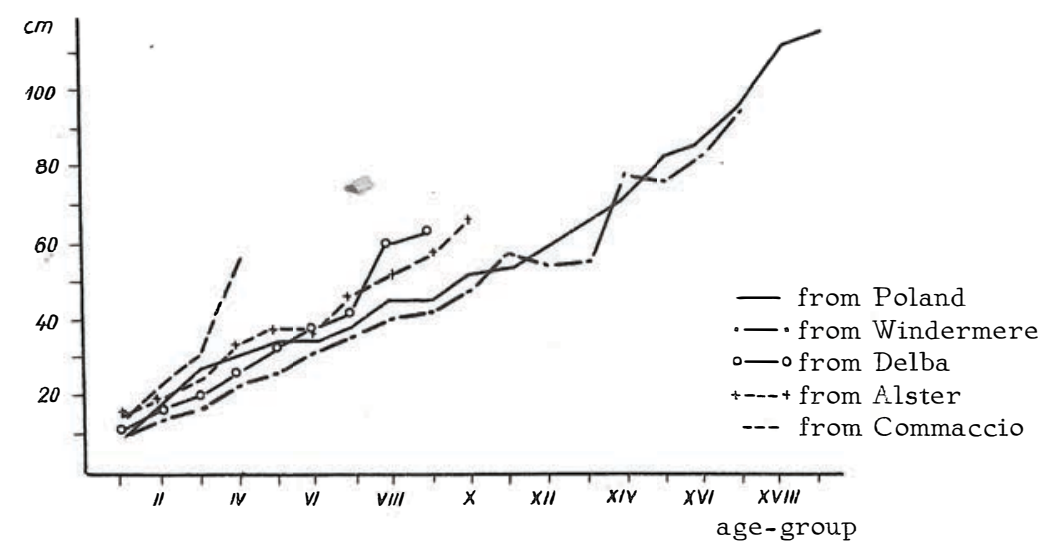

Fig.3. Length to age relation of eels from various waters

Owing to wide ranges in weight, length and age, the fact of migratory start can not be assigned as strictly relative to these values. As the main causes for fish migration should be considered the physiological changes which take place in organisms of fish and which force it to emigrate from fresh waters at various age and size.

Some authors such as, Frost (1945), B e llini (1910), Ehren$\mathrm{b}$ a u $\mathrm{m}$ and $\mathrm{N}$ a ruk o va (19i3) consider the size of fish as imperative for migration starting. T h u row (1959) ascertains, that an obtainment of breeding livery depends on some physiological changes, on annual increase of condition factors and on factor of fat accumulation. Similarly to $\mathrm{F} \mathrm{r}$ o s t (1945), he considers, that certain critical limit of young age exists which some fast-growing specimen may exceed and still remain in fresh waters. Such limit, according to Thurow falls on group IX to X at length of $57 \mathrm{~cm}$, weight of $325 \mathrm{~g}$ and with fat content of 28 per cent.

The male eels differ from females by their size, similarly to other fish species. In catches, the males are not very numberous owing to their small sizes and to limited presence, as generally they did not enter the fresh waters, but remain within the zone of estuary waters. E h r e n b a u m (1930) ascerted, that the males do not like the currents (tides) and therefore do not 
enter the fresh waters; this, however, is contradicted by the fact of males presence at Firth of Vistula River.

\section{Annual increase of length and weight}

These increases show at eels very distinctindividual deviations. The increase of length is more regular and in average amounts to $5 \mathrm{~cm}$. for younger groups and $6 \mathrm{~cm}$ for elder groups. The weight, however, increases distinctly in relation to age $\mathrm{i}$.e. from $1 \mathrm{~g}$ for group I to $1470 \mathrm{~g}$ for group XX. Fig.4.

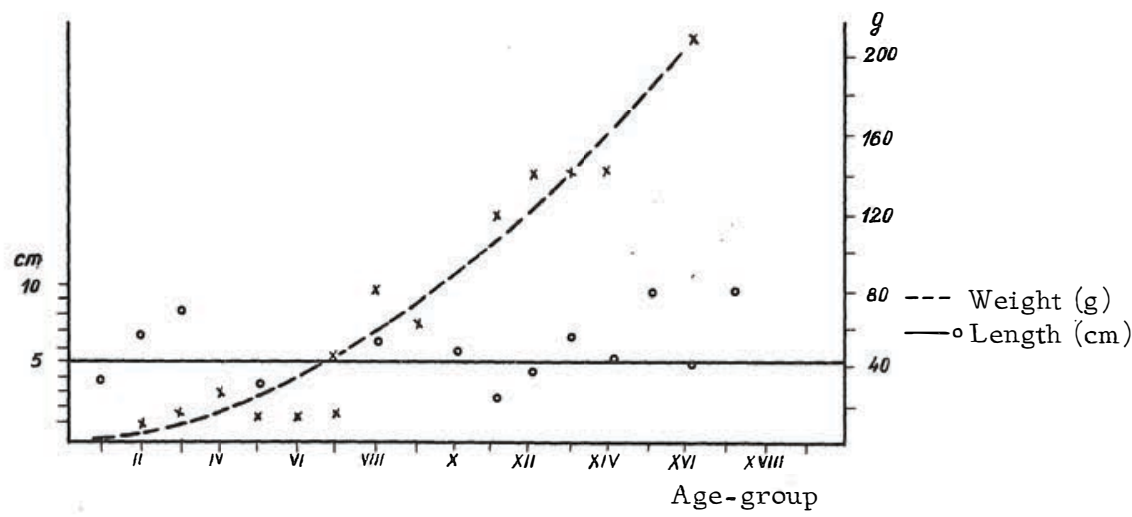

Fig.4. Curve of length and weight increase of yellow eel

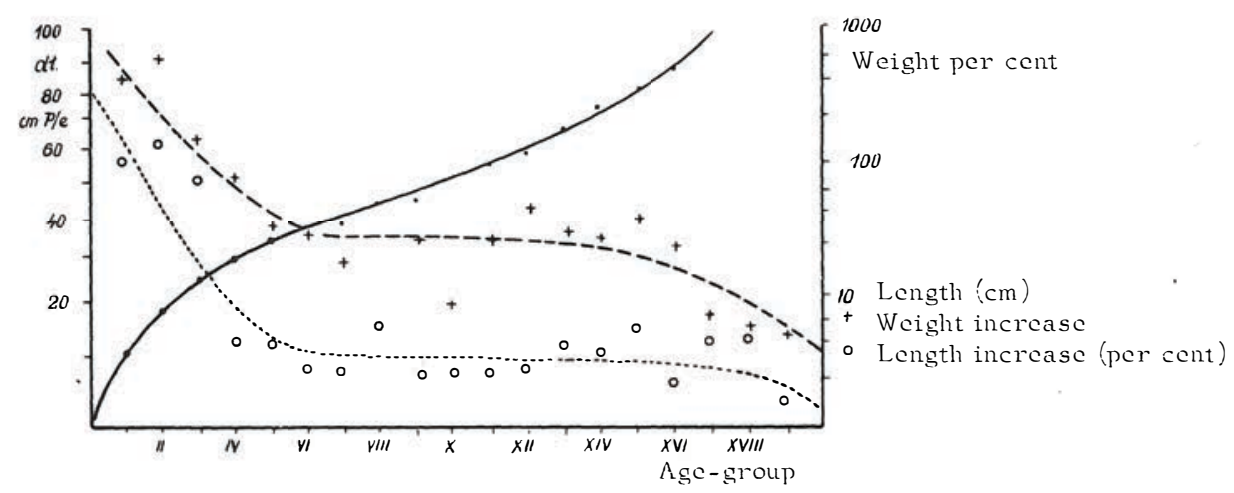

Fig.5. Proportional growth of yellow eel

Basing on this data, the value of $5.5 \mathrm{~cm}$ may be assumed as an average increase of length; this value may be taken as the basis for guidance at determination of eels age appearing in Polish waters.

The per cent increases related by $\mathrm{R} \circ \mathrm{z}$ e n s e f e $1 \mathrm{l}$ and $\mathrm{Ev}$ e r$\mathrm{h}$ a $\mathrm{rdt}$ (1953) can be applied for preparation of diagrams for the relative groups. Fig. 5 and 6 . 


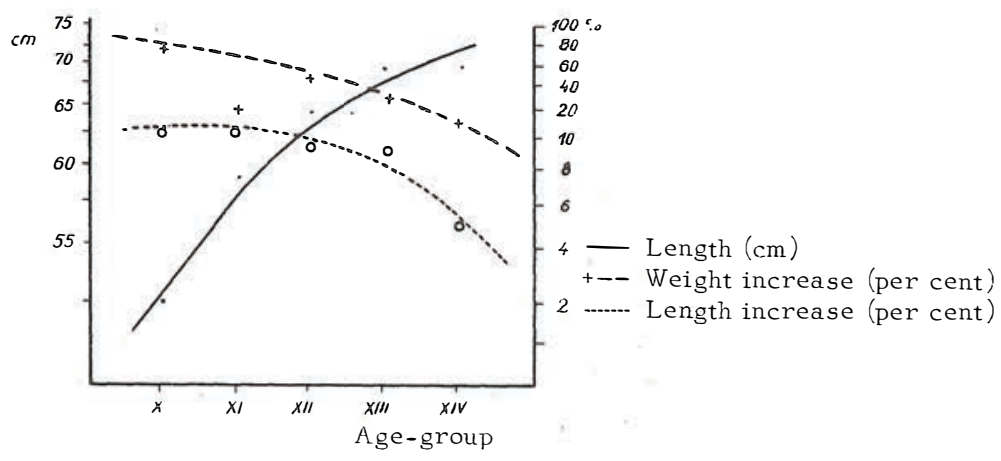

Fig.6. Proportional growth of silver eel

Curves representing the per cent increase in relation to growing length show constant fall, but at inconstant rate. Such rapid fall, corresponding to transition from intensive to slow growth, is occuring at yellow eel upto VI. and above XII. age-group. Between these periods, the fall is rather slow.

At silver eel, the curves for all age-groups are more regular and do not show any distinct deviations.

The ratio of weight to length expressed in $\mathrm{g} / \mathrm{cm}$ shows constant growth throughout the span of life of yellow eel, beginning from value of 0.13 in group I to 24.2 in group XVIII. Fig.7. At silver eels, the value is increased from 3.55 in group VIII to 10.5 in group XV for females, while for males attains 1.86 in group $V$ to 3.84 in group XI. This gives the constantly increasing advantage of weight to length increase in relation to age. For silver females, these values are generally lower than for yellow females beginning from group X. Similar, but more distinct difference, can be observed when comparing the silver males with yellow males. Beginning from group VIII, the curve representing such ratio, deviates more distinctly with age from analogical curve for females, what proves much lower increase on weight of males.

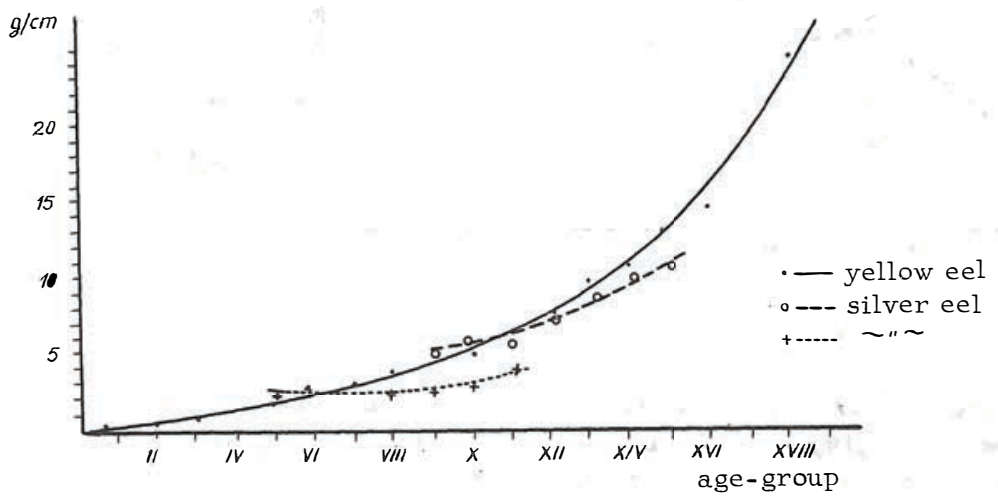

Fig. 7. Weight to length ratio $(\mathrm{g} / \mathrm{cm})$ in age-groups

The analysis of weight to length ratio without consideration of age (Fig.8) shows, that the female eels attain the characteristic specific for silver eel at the length of about $50 \mathrm{~cm}$. Thenafter, until the length of about $70 \mathrm{~cm}$, the 
silver females show lower increase of weight in relation to yellow ones, to equalise at $70 \mathrm{~cm}$. After this age, the silver females became heavier to obtain the maximum at $80 \mathrm{~cm}$, with tendency for equalisation of weight at $90 \mathrm{~cm}$. Similiar phenomenom was ascertained by $\mathrm{Fr}$ o s t (1945).

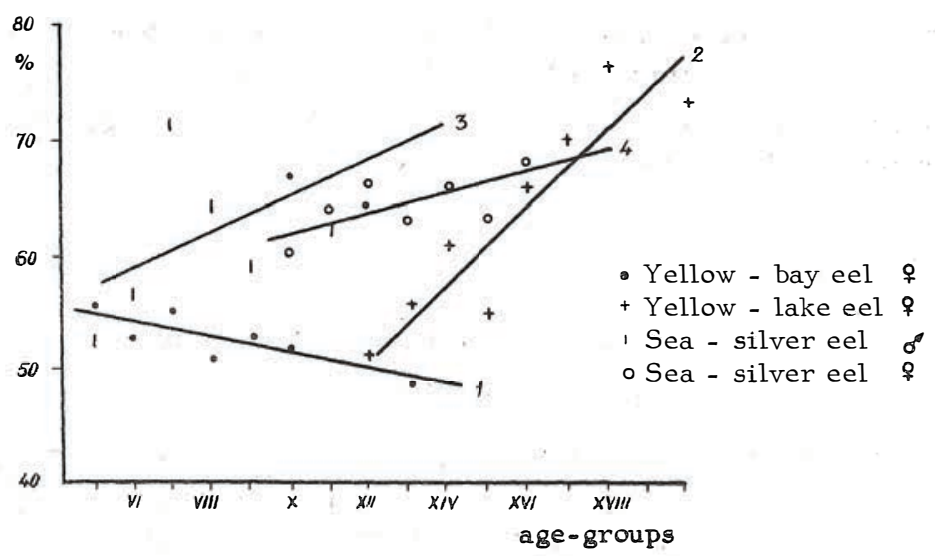

Fig.8. Weight to length ratio of eel

\section{B. Technical characteristics}

One of the basicfactors, which decides on the value of fish raw material, is the per cent content of meat tis sue by weight; this practically is considered as weight of fillets without skin. The measurement results of 258 pcs are presented on Fig. 9.

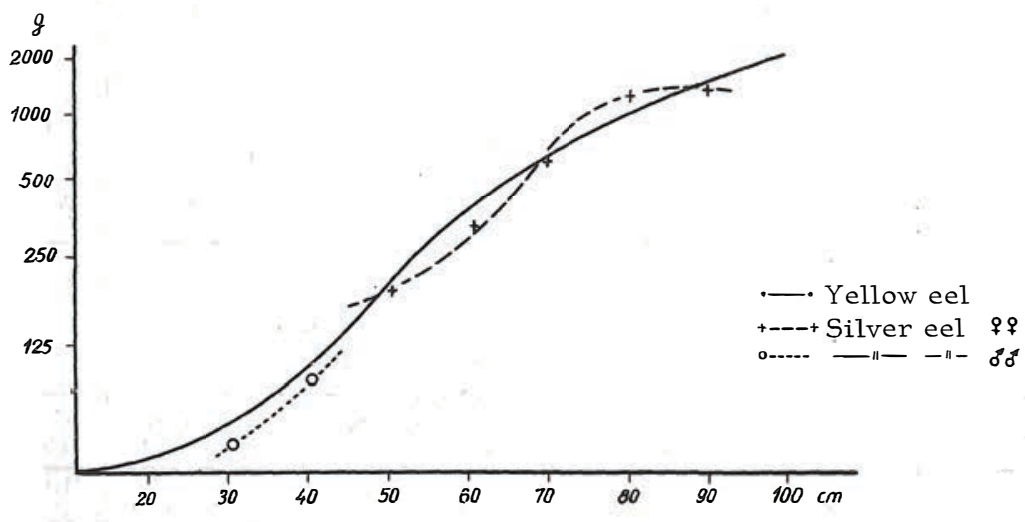

Fig.9. Per cent weight of eel fillets

The bay eel is characteristic for the lowest and slowly increasing with length, ratio of meat to weight of complete body; this is in contrary to fish coming from the remaining environments. The mostintensive in time increase of meat tissue proves the lakeeel. At silver eels, the growth of meat tissue is in direct proportion to growth of size. 
It appears from data, that the grade of muscularity is one of the factors characteristic for silver eel. The readiness for migration, except for lake fish which exceeded the length of $80 \mathrm{~cm}$ (XVI age-group), demonstrate only the specimen of high grade of muscularity relatively to given length and age.

The remaining weighed parts of body or organs of fish were in per cent decreased in relation to fish growth (Table 4 and 5).

The gonads weighed at fish of size above $71 \mathrm{~cm}$ amounted to 1.3 to 2.4 per cent of total fish weight.

$\mathrm{T}$ a b l e 4

Weight of some parts of yellow eel body

in per cent to total body weight

\begin{tabular}{|c|r|c|c|c|c|c|}
\hline $\begin{array}{c}\text { Length } \\
\mathrm{cm}\end{array}$ & $\begin{array}{c}\text { Head } \\
(\%)\end{array}$ & $\begin{array}{c}\text { Intesti- } \\
\text { nals }(\%)\end{array}$ & $\begin{array}{c}\text { Liver } \\
(\%)\end{array}$ & $\begin{array}{c}\text { Bones } \\
(\%)\end{array}$ & $\begin{array}{c}\text { Skin } \\
(\%)\end{array}$ & $\begin{array}{c}\text { Fillets } \\
(\%)\end{array}$ \\
\hline $16-20$ & 9.3 & 26.0 & - & - & - & - \\
$21-25$ & 8.0 & 27.7 & - & - & - & - \\
$26-30$ & 10.0 & 13.4 & - & - & - & - \\
$31-35$ & 7.6 & 11.4 & 2.0 & 21.0 & 11.9 & 52.7 \\
$36-40$ & 7.2 & 6.5 & 1.8 & 21.3 & 13.5 & 48.5 \\
$41-45$ & 5.2 & 7.6 & 2.2 & 19.6 & 13.6 & 52.0 \\
$46-50$ & 4.2 & 5.2 & 1.8 & 25.2 & 14.7 & 53.0 \\
$51-55$ & 5.0 & 8.7 & 2.1 & 25.4 & 15.9 & 47.4 \\
$56-60$ & 4.1 & 8.2 & 1.7 & 20.1 & 14.3 & 52.0 \\
$61-65$ & 3.7 & 7.1 & 1.6 & 24.5 & 13.8 & 53.7 \\
$66-70$ & 4.2 & 8.5 & 2.3 & 21.3 & 12.7 & 54.8 \\
$71-75$ & 4.3 & 6.1 & 3.0 & 19.0 & 12.0 & 57.5 \\
$76-80$ & 4.4 & 3.3 & 1.0 & 22.2 & 1.1 .8 & 57.8 \\
$81-85$ & 3.5 & 4.1 & 1.4 & 18.9 & 9.6 & 62.5 \\
$86-90$ & 3.5 & 3.9 & 1.3 & 17.4 & 7.9 & 67.0 \\
$96-100$ & 4.6 & 4.7 & 1.6 & 14.8 & 9.4 & 70.5 \\
\hline
\end{tabular}

Table $\tilde{J}$

Weight of some parts of silver eel body

in per cent to total body weight

\begin{tabular}{|c|r|r|r|r|r|r|}
\hline $\begin{array}{c}\text { Length } \\
\mathrm{cm}\end{array}$ & $\begin{array}{c}\text { Head } \\
(\%)\end{array}$ & $\begin{array}{c}\text { Intesti- } \\
\text { nals }(\%)\end{array}$ & $\begin{array}{c}\text { Liver } \\
(\%)\end{array}$ & $\begin{array}{c}\text { Bones } \\
(\%)\end{array}$ & $\begin{array}{c}\text { Skin } \\
(\%)\end{array}$ & $\begin{array}{c}\text { Fillets } \\
(\%)\end{array}$ \\
\hline $36-40$ & 9.0 & 4.4 & 2.0 & 12.4 & 10.0 & 63.5 \\
$41-45$ & 10.6 & 9.9 & 4.2 & 14.2 & 12.6 & 62.0 \\
$46-50$ & 5.7 & 10.0 & 2.7 & 11.9 & 12.6 & 67.7 \\
$51-55$ & 5.5 & 7.6 & 2.2 & 13.0 & 12.3 & 60.5 \\
$56-60$ & 5.7 & 5.9 & 2.3 & 12.8 & 10.2 & 64.8 \\
$61-65$ & 5.3 & 6.5 & 2.1 & 14.6 & 11.3 & 62.0 \\
$66-70$ & 4.4 & 4.9 & 2.5 & 13.2 & 11.2 & 66.0 \\
$71-75$ & 4.8 & 6.2 & 2.2 & 12.5 & 10.1 & 65.0 \\
$76-80$ & 4.5 & 4.8 & 2.4 & 10.8 & 9.2 & 67.9 \\
$81-85$ & 4.9 & 5.5 & 2.6 & 11.4 & 9.2 & 65.8 \\
$86-90$ & 4.7 & 5.6 & 2.3 & 9.7 & 9.8 & 71.5 \\
\hline
\end{tabular}




\section{CHEMICAL CHARACTERISTICS OF EEL}

Meat of eel is highly caloric with the high content of vitamins and of mineral compounds. According to Mc C a n o e (1944) it contains 12,6-19 per cent of protein and 2,19-23 per cent of fat. The mineral compounds in $\mathrm{mg}$ on each $100 \mathrm{~g}$ of meat tis sue amount to: sodium 12, potassium 207-302, calcium 323-614, magnesium 18-31, ferrum 1,3-4, phosphorus 313-475, chlorine 52-92. The content of vitamin A amounts to 0 in $1 \mathrm{~g}$ of meat tissue at glass eel and attains 9000 at silver eel. Ryboflavin for each gram amounts to $1.8-54$, nicotinic acid 3.6-24.8 irrespectably of biological condition. The lever contains not much of fat $(4,7-6,5$ per cent), but more sodium, ferrum and chlorine than any meat tissue. Skin is characteristic for high content of protein (above 25 per cent) and of ferrum (above $100 \mathrm{mg}$ for each $100 \mathrm{~g}$ ). On average, each $100 \mathrm{~g}$ of meat gives $15 \mathrm{~g}$ of proteins and 300 calories.

Wi e hr (1932), Polimonti (1913) and Shinobu Oshima (1928) ascertained irregular, but constant increase of fat quantity in relation to growth of fish. Eel accumulates the fat mainly in the subcutaneous connective tissue, from where it spreads into myomer connective tissue. Allocation of fat in meat tissue is not uniform. M a y e $r$ - W a a $r$ d e $n$ (1945) and $\mathrm{M} \circ \mathrm{r} \circ \mathrm{va}(1956)$ ascertained its highest content in the tail part and the lowest content in dorsal part. Th u row (1957) determined the content of fat in six lengths of fish. He ascertained, that the content of fat was increasing to be 12.6 per cent in first length (taking from head) to 34.8 per cent in the part before last one, to decrease in the final length to 21.6 per cent. Relatively smaller quantities of fat were determined at the wide-headed fish ( $\mathrm{T} \mathrm{h} \mathrm{u} \mathrm{r} \mathrm{o} \mathrm{w,} \mathrm{1958)} \mathrm{and} \mathrm{at} \mathrm{some} \mathrm{specimen} \mathrm{showing} \mathrm{certain} \mathrm{patalogical}$ changes ( $\mathrm{M}$ u r i n a, 1956). Toillustrate the chemical composition of meat tissue at eel, with quantitative changes in relation to age, size and sex, physiological and environment condition, effected 158 analysis and the quantities of protein, water, fat and ash were recorded (in all 632 readings).

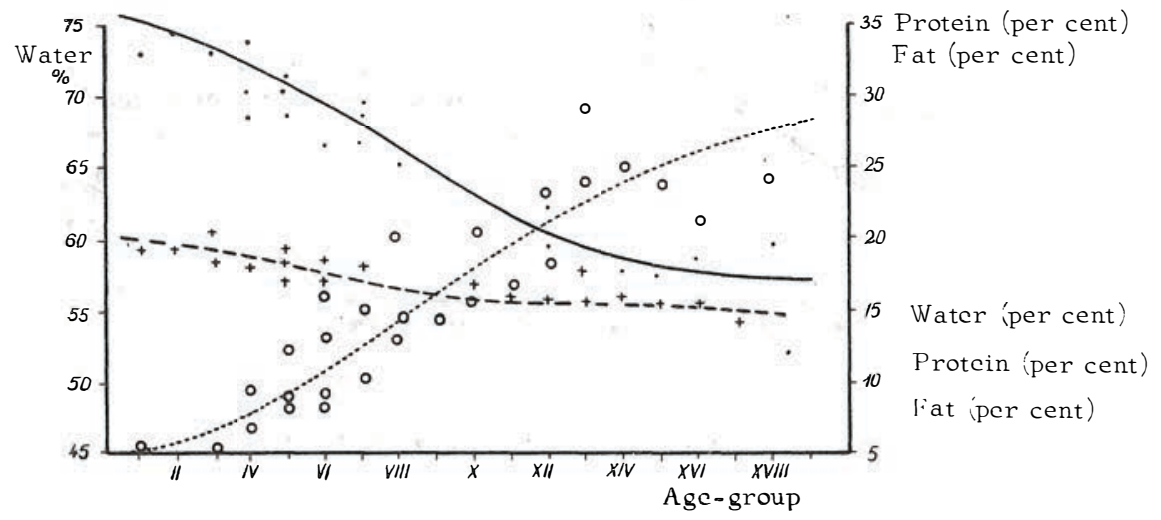

Fig.10. Chemical composition of meat tissue at yellow eel

Changes in chemical composition of yellow eel according to age-groups are presented on Fig.10.

The content of fat intensively increases with age from ab. 3 to ab. 25 per cent. Decrease of protein can be expressed from ab. 20 to ab. 14 per cent and decrease of water from ab. 75 to ab. 58 per cent. 
Fig.11 graphically presents the changes occuring in quantitative chemical composition at silver eels with respect tu age. At males, the content of protein is relatively equalised with slight decrease in relation to growth 'from $\mathrm{ab} .17$ to ab. 16 per cent); the content of water decreases from ab. 59 to ab. 52 per cent, while the content of fat increases from ab. 22 to ab. 32 per cent. At females, the content of water decreases from ab. 57 to ab. 54 per cent, protein from ab. 18 to ab. 14 per cent, while the content of fat increases from ab. 22 to $a b .30$ per cent.

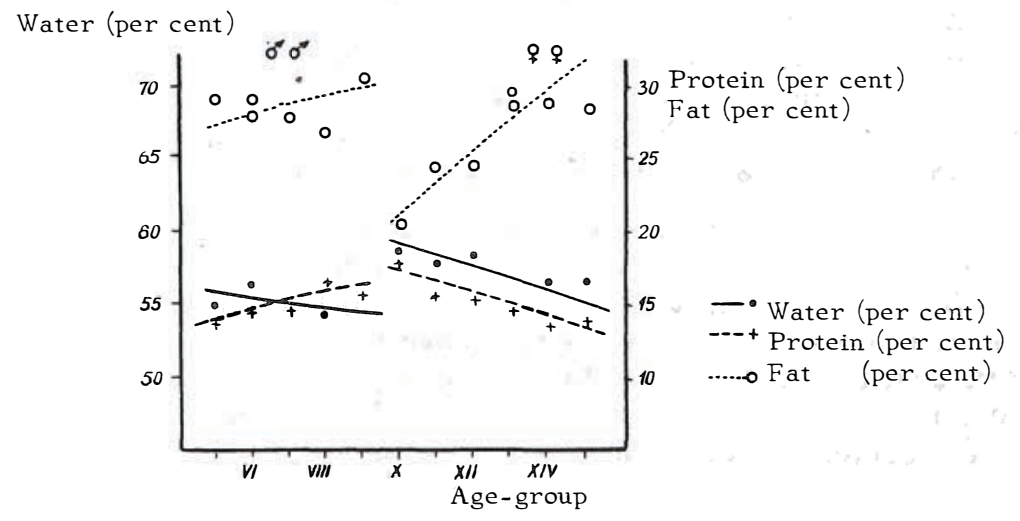

Fig.11. Chemical compostition of meat tissue at silver eel

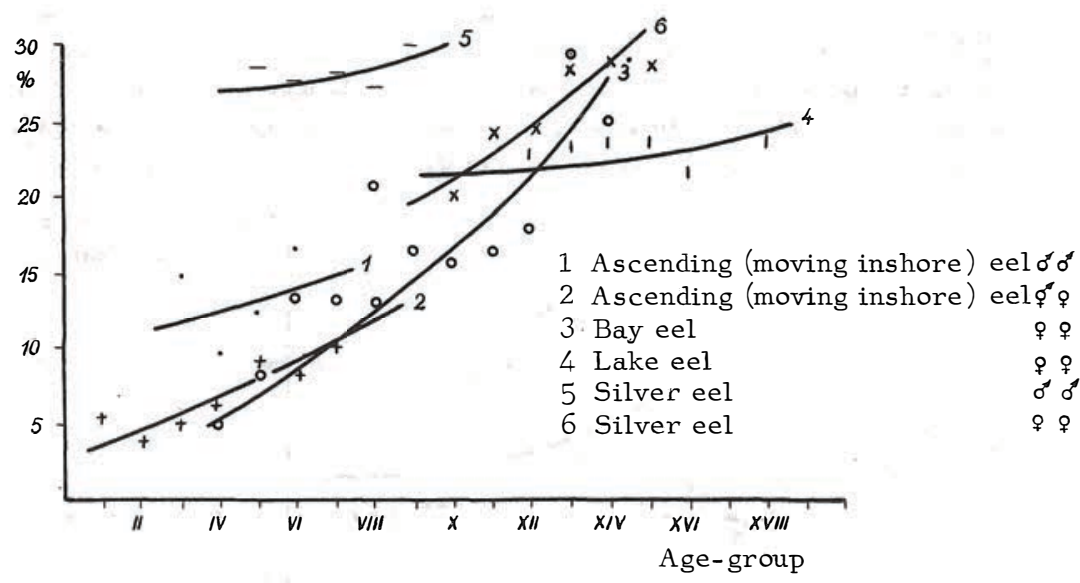

Fig.12. Content of fat in meat tissue at eel

The highest quantitative oscillations among analysed components proves the fat, which shows also distinct deviations according to environments of living (Fig.12).

The highest content of fat is noted at silver males; the females of the same length show some decrease. Further come the yellow eels, bay and lake eels. Increase of fat content in relation to growth of bay eels is lower in younger age-groups; it is, however, of higher value at elder eels in relation to lake 
eels, at which the rate of fat growing is noted to be the lowest.

It may be concluded from the above given observations, that the fat content in meat tissue is one of the conditions characteristic for attainment by silver eel. The bay eels attain sooner the minimum required and therefore are able to migrate sooner than the lake eels.

It is noted in the course of analyses, that the wide-headed eels proved quite distinct differences in their chemical composition in relation to average values. Table 6 presents the results of analyses at the wide-headed eels comperatively to average for the particular age-groups at the narrow-headed eels.

$\mathrm{T}$ a b l e 6

Chemical composition of meat tissue at narrow -

and wide-headed eels

\begin{tabular}{|l|c|c|c|c|c|c|}
\hline \multirow{2}{*}{ Age-group } & \multicolumn{6}{|c|}{ N a r r o w - h e a d e d } \\
\cline { 2 - 7 } & XII & XIII & XIV & XV & XVI & average \\
\hline Protein \% & 15.4 & 14.5 & 14.4 & 13.8 & 13.9 & 14.4 \\
Water \% & 58.3 & 58.9 & 56.5 & 57.0 & 56.4 & 57.4 \\
Fat \% & 24.6 & 25.3 & 27.2 & 24.5 & 24.0 & 25.1 \\
Ash\% & 1.0 & 0.9 & 1.0 & 1.1 & 0.9 & 1.0 \\
Analysed qty & 8 & 7 & 4 & 2 & 2 & - \\
\hline
\end{tabular}

\begin{tabular}{|l|c|c|c|c|c|c|}
\hline \multirow{2}{*}{ Age-group } & \multicolumn{7}{|c|}{ W i d e - h e a d e d } \\
\cline { 2 - 7 } & XII & XIII & XIV & XV & XVI & average \\
\hline Protein \% & 19.1 & 19.2 & 20.9 & 15.9 & 18.8 & 18.8 \\
Water \% & 66.5 & 64.3 & 6.2 .2 & 61.0 & 64.2 & 64.2 \\
Fat \% & 12.2 & 14.1 & 11.3 & 17.2 & 15.1 & 14.2 \\
Ash\% & 1.1 & 1.1 & 0.9 & 1.1 & 0.9 & 1.0 \\
Analysed qty & 1 & 1 & 1 & 1 & 1 & - \\
\hline
\end{tabular}

Progressively with age at narrow-headed eels, the content of protein decreases from 15.4 to 13.9 percent, water from 58.9 to 56.4 per cent. The wide-headed eels of analogical age-groups showed non-uniform, but higher content of protein (15.9 to 20.9 per cent) and of water (61.0 to 66.5 per cent). The content of fat, however increasing relatively to age from 12.2 to 17.2 per cent, proved lower values than analogical groups of narrow-headed eel.

In catches at Firth of Vistula River, the size classes from 30 to $44 \mathrm{~cm}$ represent 34.8 per cent quantitatively and 16.4 per cent by weight. Eel of these classes, inspite of higher flavouring aspects, represents lower caloric value and lower weight of meat tis sue (fat content from 3.4 to 13.1 per cent). By changing the protective size from 35 to $45 \mathrm{~cm}$, the annual quantity, which could be obtained world amount to 18.2 per cent. Assuming the annual fishing of 200 tons, the increase of 36.4 tons would thus be gained. This would mean additional quantity of valuable raw material when considering, that in the next year this would mean increase of fat by 3.5 per cent. 


\section{REFERENCES}

B e 11 in i A., 1910: Aalsucht - Versuche.Zeit.f.Fisch.15.

B e $r$ t i n L., 1957: Eels. A.Biological Study. Phisiol.Library Inc, New York。

E h r e n b a u m J., 1930: Der Flussaal. Binn.Fisch.Mitteleuropas. 3.

E hre $\mathrm{n} \mathrm{ba} \mathrm{um} \mathrm{J.} \mathrm{und} \mathrm{M} \mathrm{a} \mathrm{rukava,} \mathrm{1913:} \mathrm{Über} \mathrm{Alterbestimmung}$ und Wachstum beim Aal.Zeit.f.Fisch. H.14.

Frost W.E., 1945: The Age and Growth of Eels from the Windermere Catchment Area.J.of Anim.Ecol., vol.14, No 1,2.

Ge m z o e K.J., 1908: Über Alter und Wachstum des Aales. Rapp. of the Danish Biol. Station for 1906.

Gi r s z t o w t t K., 1961: Obserwacje morfologiczne nad stanem czynnościowym węgorza wstępującegoi obsadowego z okolic Szczecina. [Morphological observations on the functional state of entering and migrating eels from Szczecin region.] In manuscript. Praca magisterska przelstawiona na Wydziale Rybackim Wyższej Szkoły Rolniczej w Olsztynie.

$\mathrm{H}$ e m p e 1 O. und $\mathrm{N}$ a e $\mathrm{r}$ e $\mathrm{s}$ h e i m e r E.,1914: Über Alterbestimmung und Wachstum des Aales. Zeit.f.Fisch. H.14.

H $\circ \mathrm{rny}$ y $1 \mathrm{~d}$ A.G., 1922: The Age and the Growth of some Eels from small Warcestershire Pond. J.Roy.Microsc.Soc.London, 9-26.

H $\circ \mathrm{rny}$. $\mathrm{l}$ d A.G., 1928: L'age et la croissance de la petite anguille argentée de l'étang de Thau.Bull.Soc.Centr.Aquic.Pêch.XX.36.

H $\circ \mathrm{rnyh}$ ol d A.G., 1930: Le sexe et la croissance de la petite anguille de la roubine du pont de Rousty. Bull.Soc.Centr.Aquic.Pêch. 37.

Je s persen P., 1926: Age Determination of Eels from Norfolk and Cumberland. J.Cons. Perm. Int. Explor. Mer I.

Marcus K., 1919: Über Aaltum und Wachstum des Aales. Beiheft Jahrb. d. Hamb.Wiss.Anst. Mitt.d. Zool.Muz. 36.

Mc C a n ce R.S., 1944: The Chemistry of Growth and the Food-value of the Common Eel. Bio-chem.J.38.

M e y e $r$ - W a a $r$ d e $n$ P.F. 1945: Qualitatsuntersuchungen der Nutzfischen der Ostsee. Zeit.f.Fisch.XLI.

M $\circ \mathrm{r}$ a v a F., 1956: Die regionale Verteilung des Fettes bei verschiedenen Süsswasserfischarten. Zeit.f.Fisch. Bd.1/2.

M u rina W., 1956: Pitanije ugria w Kursom i Vislinskom Zalivach Baltijskogo Morja. (in Russian) Trudy Vsesojuznogo Gidrobiologičeskogo Obsčestva. VII., A.N...Moskva. 
N $\circ \mathrm{rdqu}$ is t O. und S.V., 1923: Untersuchungen über Aalbrut, ihre Einwanderung in der Ostsee und längst der Ostseeküste Schwedens.

P i ąt e k M., 1963: The Age Growth, Changes of Weight Proportions and Chemical Composition of Eel during its Life in Polish Waters. Intern. Coun cil for the Exp. of the Sea, Baltic-Belt Seas Committee, Nr 123.

P o l i m o n t O., 1913: Über den Fettbehalt und die biologische Bedeutung desselben für die Fische und ihren Aŭfenthaltsort. Biochem. Zentrbl. 56.

Rousensefell G.A. and Everhardt W.H., 1953: Fishery Science its Methods and Applications. N. York.

S a k o w i z (Korwin) S., 1930: Węgorz, biologia i zarys produkcji. Wyd. Przemysł Rolny.[Eel, biology and outline of production.] In Polish.

S c h m idt J., 1906: Contrubutions to the Life-History of the Eel. Rapp. P.-v. Reun. Cons.Perm. Int. Explor. Mer.5.

S c h n a c k e n b e ck W., 1953: Entwicklung des Laichhabitus beim Aal. Zool.Anz. 150 .

S c h n e i d e r G., 1909: Wachstum des Aales in Schweden. Publ.d.Circ. No 46 .

S e 1 i g o A., 1912: Der Aal. Ausdruck aus F.Z. Stettin.

$\mathrm{Sh}$ in o bu Oshm a, 1928: On the chemical changes of the Eels in the course of fasting.

S u w o r ow F., 1954: Podstawy ichtiologii Warszawa. In Polish.

T e s c h Fo, 1928: On the sex and growth investigations on the Freshwater Eel in Dutch Waters. J.Cons. Perm. Int. Explor. Mer.3-4.

Thu row F., 1957: Über die Trockensubstanz und die Kieler Foerde. Arch.f.Fisch. Wissen. 8, 1/2.

Thu row F., 1958: Untersuchungen über die Spitz und Breitköpfigen Varianten des Flussaales. Arch.f.Fisch. Wissen.9,2.

Thu r ow F., 1959: Über Fängerfrage und Wachstum des Aales in der westlichen Ostsee. Zeit.f.Fisch.VIII.

W i e h r H., 1932: Über die Chemie und Biologie der Fettsubstanzen von Aal.Zeit.f.Fisch.XXX.

W undsch H., 1910́: Neue Beiträge zu der Frage nach dem Alter und Wachstum des Aales. Zeit.f.Fisch. XXVIII. 
WIEK, WZROST I ZMIANY STOSUNKÓW WAGOWYCH ORAZ S KEADU CHEMICZNEGO WËGORZA W CZASIE JEGO ŻYCIA W WODACH POLSKI

\author{
Streszczenie
}

Węgorz odławiany w polskich wodach stanowi pod względem ilości jaki wartości poważną pozycjęekonomiczną. Dodatnie cechy organoleptyczne mięsa, jego delikatność, soczystość i wysokie walory smakowe - predystynują go jako jeden z najwartościows zych surowców rybnych dla ws zelkiego rodzaju przetwórstwa i konsumpcji.

Celem niniejszej pracy było zbadanie wzrostu i zmian stosunków wagowych oraz składu chemicznego węgorzy z najbardziej typowych, mających znaczenie gospodarcze środowisk, to jest morza, Zalewu Wiślanego i jezior, z rozbiciem na ryby żerujące i srebrzyste.

Materiał dla opracowania stanowiło 646 ryb, w tym 51 montée, 499 sztuk węgorza brunatnego (282 wstępującego z morza i ujść rzek, 151 z Zalewu Wiślanego, 66 z jezior) oraz 96 srebrzystego z morza. Wszystkie węgorze poddano ogólnym pomiarom, a oprócz tego 258 sztuk pomiarom technologicznym oraz 151 analizom chemicznym.

Wiek ryb badano na podstawie otolitów, przygotowując je do odczytu według opracowanej metody polegającejna zanurzaniu przez 24 godz. w alkoholu, szlifowaniu i umieszczaniu na płytce $z$ czarnym tłem w balsamie kanadyjskim, oznaczając go w grupach, wyrażającychilośćlat spędzonych w wodach słodkich lub wysłodzonych, oznaczanych według ilości ukończonych pierścieni rocznych.

Zebrany materiał należał do grup wieku od 0 do XX, przy rozpiętości długości całkowitej ryb od 7 do $115 \mathrm{~cm}$, a ciężaru od 0,5 g do $2750 \mathrm{~g}$. Uzyskane dane zestawiono jako stosunek długości i ciężaru do wieku, celem możliwości porównania $\mathrm{z}$ wynikami innych autorów.

Węgorze wstępują do naszych wód słodkich i wysłodzonych w grupach wie$\mathrm{ku}$ od I do IX, przeciętnie V, odpowiadającej całkowitemu wiekowi ryb 8 lat, o przeciętnej długości 33,6 cm oraz ciężarze 64,8 g. Samce posiadają przeciętny wiek 7,2 lat (V grupa) długość $32,8 \mathrm{~cm}$, ciężar $55,8 \mathrm{~g}$, samice natomiast 8,2 lat (VI grupa), długość $34,6 \mathrm{~cm}$ i ciężar $66,8 \mathrm{~g}$. Samce wykazywały lepszą kondycję od samic $0,59 \mathrm{~g} / \mathrm{cm}$ wobec $0,51 \mathrm{~g} / \mathrm{cm}$. Węgorze wstępujące cechują się zbliżoną długością do zalewowych w młodszych jedynie grupach wieku, w starszych natomiast długość ich jest mniejsza.

W materiale z Zalewu Wiślanego stwierdzono jedynie obecność samic o przeciętnym wieku 10 lat (VII grupa), długości 42,3cm i ciężarze $163 \mathrm{~g}$. Wykazywały one jednakowe przyrosty długości na przestrzeni życia w tym środowisku, natomiast przyrosty ciężaru w miarę wieku stawały się coraz wyższe.

Węgorze jeziorowe - także wyłącznie samice - wykazywały przeciętny wiek 13 lat (X grupa), długość 65,9 cm i ciężar $698 \mathrm{~g}$. Do XX grupy wieku wykazują one większe długości niż zalewowe, od IX do XIII niższe, a powyżej 
znów wyższe, równomiernie przyrastające w miarę wieku。Przyrosty ich są intensywniejsze niż węgorzy zalewowych. Ciężary natomiast w tych samych grupach wieku przyrastają w tym samym tempie.

Węgorze srebrzyste - samce - posiadały przeciętny wiek 10,3 lat (VII grupa), długość 38,6 cm i ciężar $97 \mathrm{~g}$, a samice 15,3 lat (XII grupa), długość $64,5 \mathrm{~cm}$ i ciężar $524 \mathrm{~g}$. Stosunek ciężaru do długości w grupach wieku w porównaniu $z$ węgorzami brunatnymi po początkowo wyższych wartościach (samce do VII grupy, samice doX) staje sięw miarę wieku corazniższy, wykazując coraz mniejsze przyrosty w stosunku do brunatnego.

Przeciętny, obliczony na podstawie przeprowadzonych pomiarów przyrost długości węgorza w wodach polskich wynosi $5,5 \mathrm{~cm}$ rocznie, która to wielkość może służyć do orientacyjnego określenia wieku ryb.

Stwierdzono iż wzrost długości ciała węgorza w wodach słodkich jest prawie równomierny; minimalnie zwięks zając się z wiekiem ryb. W zrost ciężaru z wiekiem ryb jest szybszy niż długość.

Najwyższym procentem wagowym tkanki mięsnej dla danego wieku cechują się srebrzyste samce, a najniższym, nawetmalejącym w miarę wieku zalewowe. Natomiast najsilniejszym przyrostem ciężaru tkanki mięsnej charakteryzują się węgorze jeziorowe.

Poszczególne organa i części ciała węgorzy prócz mięśni i gonad wykazują stopniowy, choć nieregularny, procentowy spadek ciężaru.

Najsilniejszym zmianom ilościowym na przestrzeni życia węgorza podlega tłuszcz, rosnąc z wiekiem i długością ryb od około 2 do ponad 30\%. Zarówno białko jak i woda wykazujątendencjęmalejącą, popiół natomiastutrzymuje się niemal na jednolitym poziomie. Najwyższy procent tłuszçzu w tym samym wieku mają węgorze srebrzyste, a zwłaszcza samce. Najsilniejsze tempo wzrostu tłuszczu z wiekiem posiadają węgorze zalewowe, a najniższe jeziorowe. Brak węgorzy w Zalewie powyżej dług. $80 \mathrm{~cm}$ świadczy, iż uzyskały one odpowiedni procenttłuszczui migrowały z tych wód. Natomiast wolno wzrastającailość tłuszczu u węgorzy jeziorowych wskazuje na oddalony termin ich migracji. Samce, zarówno srebrzyste jak i brunatne posiadają wyższy procent tłuszczu niż samice w tym samym wieku.

Różnice między węgorzami szeroko i wąskogłowymi polegają na niższej zawartości tłuszczu a wyższej wodyi białka, niższych ciężarach a wyższych długościach dla poszczególnych grup wieku, a więc gorszej kondycji.

Węgorze srebrzyste różnią się od brunatnych stosunkiem wieku do długości i ciężaru, ciężaru do długości, procentową ilością tkanki mięsnej, tłuszczu, barwą skóry, wypełnieniem przewodu pokarmowego, wielkością gonad i średnicą oka, która jest u srebrzystych około 50\% większa.

Węgorz Zalewu Wiślanego ogólnie, a zwłaszcza ryby o wielkości 30 do $44 \mathrm{~cm}$ cechują się najniższą wartością kaloryczną oraz procentem tkanki mięsnej. Podwyższenie wymiaru ochronnego z 35 na $45 \mathrm{~cm}$, przez zwiększenie średnicy oczek sieci, dałoby w efekcie około 40 ton rocznie więcej wartościowego surowca dla przetwórstwa i konsumpcji.

Klasy wielkości od 30 do 4 cm stanowią w odłowach Zalewu Wiślanego $34,8 \%$ ilościowo i $16,4 \%$ wagowo. Węgorz z tych klas, pomimo. że cechuie 
się dodatnimi walorami smakowymi i chętnie nabywany jest przez konsumentów w stanie wędzonym, przedstawia niską wartość kaloryczną (zawartość tłuszczu od 3,4 do $13,1 \%$ ) a również procent wagowy jego tkanki mięsnej jest stosunkowo niższy (48,5 do 52\%). Pozostawiając gow Zalewie dla wyrośnięcia przez podwyższenie wymiaru ochronnego do $45 \mathrm{~cm}$ (dotychczas obowiązujący wymiar ochronny wynosi $35 \mathrm{~cm}$ ), zyskałoby się rocznie 18,2\% masy więcej, czyli przy odłowach wynoszących przecięlnie 200 ton rocznie można uzyskać dodatkowo 36,4 ton. Jest to poważna, dodatkowa ilość cennego surowca tym cenniejsza, że już w następnym roku posiadająca przeciętnie o 3, $5 \%$ tłuszczu więcej.

Węgorz wstępujący, będący o najniżs zych wartościach kalorycznych (zawartość tłuszczu przeciętnie 7,8\%) powinien być odławiany jedynie w celach zarybieniowych i to przede wszystkimwujściachrzek, w których ze względu na bariery biologiczne oraz spiętrzenia ma utrudnione względnie całkiem uniemożliwione wstępowanie.

\section{ВОЗРАСТ, РОСТ И ИЗМЕНЕНИЯ ВЕСОВЫХ СООТНОШЕНИЙ И ХИМИЧЕСКОГО СОСТАВА УГРЯ В ПЕРИОД ЕГО ЖИЗНИ В ВОДАХ ПОЛЬШИ}

\section{P}

Угорь, вылавливаемый в польских водах, с точки зрения как количества, так и ценности является серьёзной эгономической позицией. Положительные органолептические качества мяса, его деликатность, сочность и высокие вкусовые качества делают его одним из самых ценных сырьевых рыбных материалов для всякого рода переработки и потребления.

Целью настоящей работы было исследование роста и изменений весовых соотношений, а также химического состава угря из наиболее типичных, имеющих хозяйственное значение, водоёмов. т.е. моря: Вислинского залива и озёр, с разделением на нагульную и покатную рыбу.

Материалом для обработки явились 646 штук угря, в том числе 51 - стеюлянный угорь, 499 штук - бурый угорь (282 - входящие из моря и у устьев рек, 151 - из Вислинского залива, 66 - из озёр), а также 96 штук серебристого угря из моря. Весь угорь был подвергнут общему измерению, кроме того 258 штук - технологическим измерениям, а 151 - химическим анализам.

Возраст рыбы исследовали на основе отолитов, приготавливая их для отсчёта по разработанному методу, заключаюемуся в гогружении в алкоголь на 24 часа, шлифорке и умещении на пластинке с чёрным фооном в канадском 
бальзаме. Исследуемую рыбу распределяли по возрастным групнам, выражающим количество лет, проведенных в пресных или опреснённых водах.Последнее определяли по количеству законченных тодичных колец.

Собранный материал относился к возрастным группам от 0 до XX, при диапазоне полной длины рыбы от 7 до 115 см и веса от 0,5 г до 2750 г.Полученные данные сопоставлены как соотношение длины и веса к возрасту с целью сравнения этих данных с результатами других авторов.

Угорь входит в наши пресные и опреснённые воды в возрастных группах от 0 до IX, в среднем V, что соответствует полному возрасту рыбы 8 лет, со средней длиной 33,6 см и весом 64,8 г. Средний возраст самцов составляет 7,2 года (V группа), длина их 32,8 см, вес 55,8 г, в то время как средний возраст самок составляет 8,2 года ( VI группа), длина 34,6 см и вес 66,8 г. Самцы характеризовались лучшей кондицией, чем самки: 0,59 г/см по сравнению с 0,51 г/см. Входящий угорь имел длину подобную длине угря, обитающего в заливе иоключительно в младиих возрастных группах; в старших же длина его является меньшей.

В материале из Вислинского залива констатировано только наличие самок, средний возраст которых составлял 10 лет (VII группа), длина - 42,3 см и вес - 163 г。 Наблюдалось у них одинаковое увеличение длины на протяжении жизни в этой среде; прирост веса с увеличением возраста становился всё больше.

Озёрный угорь - также исключительно самки - характеризовался средним возрастом 13 лет ( $\mathrm{X}$ группа), длиной в 65,9 см и вес.ом в 698 г。 До ХХ возрастной группы длина их была большей, чем у обитающи в заливе, от IX до XIII - меньшей, а выше - снова большей, равномерно возрастаюей по мере увеличения возраста. Прирост озёрного угря был более интенсивным, чем у угря, обитаюего в заливе. Вес же в тех же возрастных группах увеличивался в том же темпе.

Серебристый угорь - самцы - имел средний возраст 10,3 года (vII груп. па), длину 38,6 см и вес 97 г., а самки - 15,3 года (XII группа), длину 64,5 см и вес 524 г. Соотношение веса и длины в возрастных группах по сравнению с бурым угрём с болге высокими исходными данными (самцы до VII группы, самки до $\mathrm{X}$ ) становится с увеличением возраста всё ниже, проявляя всё меньший прирост по сравнению с бурым.

Средний, подсчитанный на основе произведенных измерений прирост длины угря в польских водоёмах составляет 5,5 см в год, что может служить для ориентировочного определения возраста рыбы.

Установлено, что рост длины тела угря в пресных водах лвляется почти равномерным, минимально уменьнающися по мере увеличения возраста рыбы. Увеличение веса с увеличением возраста рыбы является более быстрым, чем увеличение длины .

Самым высоким весовым процентом мясной ткани для данного возраста характеризуются самцы серебристого угря, а самым низким, и даже уменьшающимся, с увеличением возраста, обитаюие в заливе. Самым высоким приростом веса мясной ткани характеризуется озёрный угорь. 
Отдельные органы и части тела угря, кроме мышц и гонад, прояв Іяют постепенное, хотя и нерегулярное, процентное снижение веса.

Самым сильным количественным изменениям на протяжении жизни упря подвергается жир, который увеличивается вместе с увеличением возраста и длины рыбы приблизительно от 2 до 30\%. Как белок, так и вода проявляют уменьшающуюся тенденцию, зола же продолжает оставаться почти на одном и том же уровне. Самый высожий процент жира в одном пл том же возрасте имеет серебристый угорь, а особенно самцы. Самый силєный темп роста жира с увеличением возраста имеет угорь, обитаюий в заливе, а самый низкий - озёрный. Отсутствие в Вислинском заливе угря длиннее $80 \mathrm{~cm}$ свидетельствует о том, что он приобрёл соответствующй процент жира и мигрировал из этих вод. Медленное возрастание количества жира у озёрного угря указывает на отдалённый срок его митрации, Самцы, как серебристые, так и бурые, имеют более высокий процент жира, чем самки того же возраста.

Разница между угрём широко - и узкоголовыми заключается в более низком содержании жира, однако более высоком содержании воды и белка,меньшем весе и большей длине для отдельных возрастных групп, а следовательно более слабой кондиции。

Серебристый угорь отличается от бурого соотношением возраста и длины и веса, веса и длины, процентным количеством мясной ткани, жира, цветом кожи, наполнением пищевода, величиной гонад и диаметром глаза, который у серебристого угря приблизительно на 50\% больше.

Угорє из Вислинского залива вообще, а рыбы размером от 30 до 44 см особенно, характеризуются самой низкой калорийностью, а также процентом мясной ткани. Повышение защитного размера с 35 до 45 см путём увеличения диаметра ячеек сети'дало бы в результате около 40 тонн в год больше ценного сырья для переработки и потребления.

Классы величин от 30 до 44 см составляют в уловах Вислинского залива $34,8 \%$ в количественном и 16,4\% в весовом отношениях. Угорь из этих классов несмотря на то, что хараитеризуется положительными вкусовыми качествами и охотно покупается потребителем в копчёном виде, имеет низкую калорийность (содержание жира от 3,4 до 13,1\%), а весовой процент ето мясной ткани является относительно более низким (48,5 до 52\%)。 Оставляя его в заливе для росста путём повышения защитного размера до 45 см (до настоящего времени обязательный защитный размер составлял 35 см), можно было бы получить в год на 18,2\% рыбы больше, т॰е. при уловах, составляющих в среднем 200 тонн в год можно получить дополнительно 36,4 тонны。 Это серьёзное доголнительное количество ценного сырья, тем более ценного, что уже в следующем году имело бы в среднем на 3,5\% жира больше.

Входящий угорь, обладающий самыми низкими калорийными качествами (содержание жира в среднем 7,8\%) должен вылавливаться тслько в целях зарыбления и прежде всего в устьях рек, в которых из-за биологических барьеров, а тағще нагромождения вод вход является затруднённым или же вообще невозможным 。

Address:

Dr Mieczysław Piatek

Katedra Ichtiobiologii WSR

Szczecin, ul. Kazimierza Królewicza 4

Polska-Poland

Received 10.IX.1969 